Egyptian Journal of Aquatic Biology \& Fisheries

Zoology Department, Faculty of Science,

Ain Shams University, Cairo, Egypt.

ISSN $1110-6131$

Vol. 25(3): $589-606$ (2021)

www.ejabf.journals.ekb.eg

\title{
The Influence of Discharge Effluents on the River Nile Water Quality at Aswan Governorate, Egypt
}

\section{Sayeda M. Ali ${ }^{1, *}$, Hesham A. Abo El-Magd², Ahmed D. El-Gamal ${ }^{3}$, Magdy M. Afifi ${ }^{2}$ and Amr H. Fouda ${ }^{3}$}

${ }^{1}$ Microbiology Department, National Institute of Oceanography and Fisheries, Aswan Research Station, Egypt

${ }^{2}$ Botany and Microbiology Dept., Faculty of Science (boys), Al-Azhar University, Assiut, Egypt.

${ }^{3}$ Botany and Microbiology Dept., Faculty of Science (boys), Al-Azhar University, Cairo, Nasr City, Egypt.

*Corresponding author: malisayeda@yahoo.com

\section{ARTICLE INFO}

Article History:

Received: Nov. 5, 2020

Accepted: April 27, 2021

Online: June 25, 2021

Keywords:

River Nile pollution, Microbial water quality, Chemical water quality, Water quality index

\section{ABSTRACT}

The disposal of El-Sail drain, Kom Ombo drain, Edfu ferroalloys factory, and Edfu sugar cane factory around Aswan city poses a serious threat to the River Nile waters, especially El-Sail and Kom Ombo drains which recorded higher microbial load. Kom Ombo drain recorded higher total bacterial counts (TBC) at $22{ }^{\circ} \mathrm{C}\left(1800 \times 10^{3} \mathrm{cfu} / \mathrm{ml}\right)$, thermophilic bacteria $(259$ $\mathrm{cfu} / \mathrm{ml})$ and spore-forming bacteria $\left(15.8 \times 10^{3} \mathrm{cfu} / \mathrm{ml}\right)$. While El-Sail drain recorded higher TBC at $37{ }^{\circ} \mathrm{C}\left(137 \times 10^{3} \mathrm{cfu} / \mathrm{ml}\right)$ and higher values for indicator bacteria (total coliforms, faecal coliforms, and faecal streptococci). In addition, warmer seasons (spring and summer) showed higher counts of indicator bacteria Salmonella sp. and Shigella sp. in 22 and $30 \%$ of samples, respectively, whereas Escherichia coli was detected in all sites, recording the highest values at El-Sail drain samples. Furthermore, El-Sail drain samples recorded the highest values for electrical conductivity, total dissolved solids, biochemical oxygen demand, $\mathrm{NH}_{3}, \mathrm{NO}_{2}{ }^{-}$and $\mathrm{PO}_{4}{ }^{3-}$, while Kom Ombo drain samples recorded the highest values for water temperature and $\mathrm{NO}_{3}{ }^{-}$. Ranks of water quality index (WQI) were good in all sites, except for the disposal sites which ranged from fair to marginal. In conclusion, the River Nile water at Aswan governorate is heavily polluted, especially at ElSail drain and Kom Ombo drain. Consequently, treatment and safe disposal of different industrial and domestic wastes are recommended.

\section{INTRODUCTION}

Pumped pollutants (undesirable substances) change the natural properties of water and damage the aquatic system, and hence, it is dangerous for aquatic organisms (Canli \& Kalay, 1988; Nda et al., 2018). The River Nile is the main source of freshwater in Egypt, therefore it must be maintained with good quality. In this context, many studies have been conducted to monitor and control freshwater, through addressing 
microbiological, physical, and chemical measurements (Soltan, 1991; Awadallah et al., 1993; Ismail \& Ramadan, 1995; Abdel-Satar \& Elewa, 2001; Ali et al., 2015; Rawway et al., 2016; El-Sheekh et al., 2018; Elbadry, 2019). It is worth mentioning that, microbial contamination is one of the most important factors of water pollution, especially pathogenic microorganisms (Rawway et al., 2016). Faecal coliform and streptococcus bacteria have also been used to indicate contamination of water with feces, and this is a risk to human health because this means that the water source receives large amounts of domestic and agricultural waste, and there is also a high possibility of a large number of pathogenic bacteria (Ali et al., 2000).

The quality of the Nile water varies with regard to place and time. It is affected by human activities (e.g. population, industry, fishing, and agriculture) and seasonal change (e.g. floods and cold or hot seasons). Additionally, the quantities and qualities of wastewater effluents are major influences on water quality (Ali $\boldsymbol{e t}$ al., 2011). There is no significant pollution at the beginning of the Nile flow in the far south of Egypt (Othman et al., 2016). But, with the beginning of human activities, and at every point of discharge, contaminated water has been observed (Ali et al., 2011; Ali et al., 2016).

Many indexes have been used to determine water quality and pollution rate. For example, the contamination index (CI) measures the relative contamination of different metals in the separated and combined state (Backman et al., 1998). The heavy metal pollution index $(H P I)$ is an effective estimating method to evaluate water quality with respect to heavy metals (Zakhem \& Hafez, 2015). Aquatic toxicity index (ATI) was developed by Wepener $\boldsymbol{e t}$ al. (1992) to estimate the health of aquatic ecosystems based on the effects of water parameters on fish health. The water quality index (WQI) is the most important index for the evaluation of water quality. The calculation of WQ1 is based on the number of physicochemical and bacteriological parameters (Poonam et al., 2013). Water quality index displays the grade of water quality in rivers, lakes, and streams and addresses the water quality data in simple expressions as excellent, good, and bad (Al-Shujairi, 2013).

Four visible drains were detected in Aswan Governorate, namely; 1) El-Sail drain, which receives domestic and industrial wastewater from Egyptian chemical industries (KIMA), and factories that produce nitrogenous fertilizers and chemical materials. The drainage rate is about 56-70 $\mathrm{km}^{3} /$ day released into the River Nile (Ahmed, 2015 \& Ali et al., 2015), 2) Kom Ombo drain, which receives agricultural and industrial wastewater from Kom Ombo sugar cane factory. The drainage rate is about $143.9 \mathrm{~km}^{3} /$ day released into the River Nile (APRP, 2002), 3) Edfu ferroalloys company drain, which receives the industrial wastewater which is directly discharged into the River Nile, and 4) Edfu sugar cane factory drain, which receives the industrial wastewater. The drainage rate is about $268.9 \mathrm{~km}^{3} /$ day released into the River Nile (APRP, 2002). 
The present study was conducted to examine the effect of visible drainage effluents on the River Nile water quality in Aswan Governorate, through microbiological and chemical analysis and water quality index WQI calculations.

\section{MATERIALS AND METHODS}

\section{Study Area}

Water samples were collected seasonally (from April 2017 to January 2018) from five sectors with three samples from each sector (east, west and middle), four sectors represented main visible discharge drains in the governorate of Aswan (El-Sail, Kom Ombo, Edfu ferroalloys and Edfu sugar cane factory) and one sector represented invisible discharge effluents (Gabal Taqouq) (Figure 1).

\section{Collection of water sampling}

Water samples were aseptically collected in sterilized $500 \mathrm{ml}$ glass bottles for bacteriological determinations and in $1000 \mathrm{ml}$ bottles for physicochemical analyses.

\section{Analyses of water sampling}

\subsection{Bacteriological analyses}

\subsubsection{Major bacterial groups}

Bacteriological analyses of water samples included counting of total viable bacterial counts (TBC) at $22^{\circ} \mathrm{C}$ and at $37^{\circ} \mathrm{C}$, in addition to the total spore-forming bacteria (SFB) (after pasteurization of samples for $15 \mathrm{~min}$ at $80^{\circ} \mathrm{C}$, and incubation at $32^{\circ} \mathrm{C}$ ), and total thermophilic bacteria $(\mathrm{ThB})$ (incubation at $55^{\circ} \mathrm{C}$ ), using pour plate technique with plate count agar medium (APHA, 1998).

\subsubsection{Bacterial indicators of sewage pollution}

Bacterial indicators of sewage pollution included counting of total coliforms (TC) and faecal coliforms (FC) in MacConkey broth medium, and faecal streptococci (FS) in azide-dextrose broth medium using MPN method (APHA, 1998).

\subsubsection{Pathogenic bacteria}

Salmonella sp., Shigella sp. and E. coli were enumerated and isolated using surface plate technique and salmonella-shigella agar medium and incubated at $35^{\circ} \mathrm{C}$ for 24 and 48 hours (APHA, 1998). Automated identification for these bacterial isolates was determined using the Biomerieux Vitek 2 System (at the Central Laboratories, Ain Sham University Hospitals).

\subsection{Physicochemical properties}

\subsection{1. $\mathrm{pH}$, electrical conductivity, total dissolved solids and temperature}

The $\mathrm{pH}$ of water, electrical conductivity (EC), total dissolved solids (TDS) and water temperature (Temp.) were measured using a $\mathrm{pH}$-meter, Crison Multimeter $\mathrm{MM}^{4} 0^{+}$ (APHA, 1998).

\subsubsection{Dissolved oxygen (DO)}

DO was estimated according to APHA (1998). 


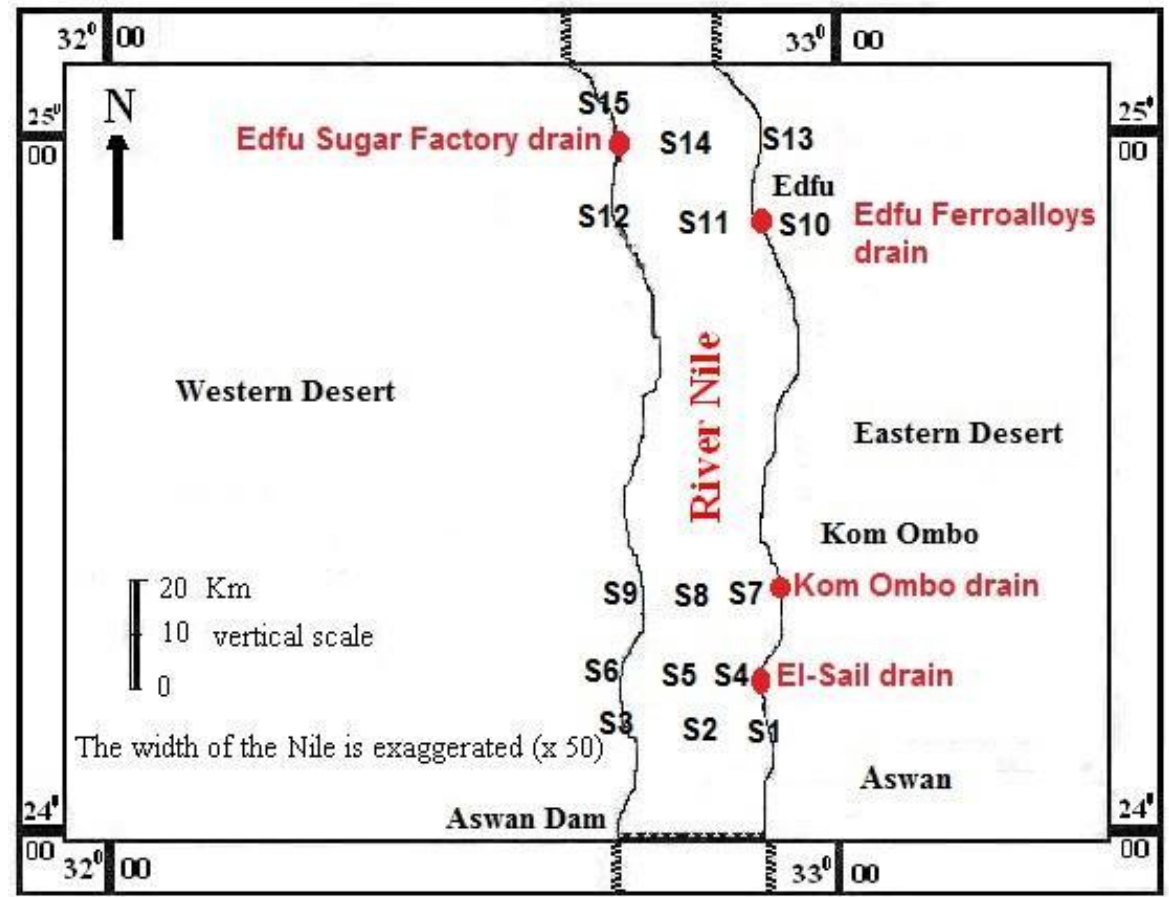

Fig. 1. Sampling sites from the River Nile in Aswan, Egypt; following are further descriptions of the sampling sites and GPS data:

\begin{tabular}{|c|c|c|c|c|}
\hline Code & Sector & Site & GPS data & Description \\
\hline $\begin{array}{l}\mathrm{S}_{1} \\
\mathrm{~S}_{2} \\
\mathrm{~S}_{3}\end{array}$ & $\begin{array}{l}\text { Gabal Taqouq } \\
\text { (Sector } 1 \text { ) }\end{array}$ & $\begin{array}{l}\text { East } \\
\text { Middle } \\
\text { West }\end{array}$ & $\begin{array}{l}24^{\circ} 4^{\prime} 56.32874^{\prime \prime} / 32^{\circ} 53^{`} 10.33356^{\prime \prime} \\
24^{\circ} 44^{\prime} 58.78693^{\prime \prime} / 32^{\circ} 53^{`} 10.13251^{\prime \prime} \\
24^{\circ} 5{ }^{\prime} 4.70581^{\prime \prime} / 32^{\circ} 52^{`} 55.09003^{\prime \prime}\end{array}$ & $\begin{array}{l}\text { In front of OLD CATARACT Hotel } \\
\text { Main channel of the River Nile } \\
\text { In front of AMON Hotel }\end{array}$ \\
\hline $\begin{array}{l}\mathrm{S}_{4} \\
\mathrm{~S}_{5} \\
\mathrm{~S}_{6}\end{array}$ & $\begin{array}{l}\text { El-Sail drain } \\
\text { (Sector 2) }\end{array}$ & $\begin{array}{l}\text { East } \\
\text { Middle } \\
\text { West }\end{array}$ & $\begin{array}{l}24^{\circ} 6{ }^{`} 59.79446^{\prime \prime} / 32^{\circ} 53^{`} 56.79199^{\prime \prime} \\
24^{\circ} 77^{\prime} 75056^{\prime \prime} / 32^{\circ} 53^{`} 44.10278^{\prime \prime} \\
24^{\circ} 77^{\prime} .52731^{\prime \prime} / 32^{\circ} 53^{`} 34.69574^{\prime \prime}\end{array}$ & $\begin{array}{l}\text { In front of El-Sail drain } \\
\text { Main channel of the River Nile } \\
\text { On the other side of El-Sail drain }\end{array}$ \\
\hline $\begin{array}{l}\mathrm{S}_{7} \\
\mathrm{~S}_{8} \\
\mathrm{~S}_{9}\end{array}$ & $\begin{array}{l}\text { Kom Ombo drain } \\
\text { (Sector 3) }\end{array}$ & $\begin{array}{l}\text { East } \\
\text { Middle } \\
\text { West }\end{array}$ & $\begin{array}{l}24^{\circ} 27^{\prime} 22.51785^{\prime \prime} / 32^{\circ} 55^{\prime} 33.60901^{\prime \prime} \\
24^{\circ} 27^{\prime} 21.62521^{\prime \prime} / 32^{\circ} 55^{\prime} 21.70258^{\prime \prime} \\
24^{\circ} 27^{\prime} 11.45599^{\prime \prime} / 32^{\circ} 55^{\prime} 9.86481^{\prime \prime}\end{array}$ & $\begin{array}{l}\text { In front of Kom Ombo drain } \\
\text { Main channel of the River Nile } \\
\text { On the other side of Kom Ombo drain }\end{array}$ \\
\hline $\begin{array}{l}S_{10} \\
S_{11} \\
S_{12}\end{array}$ & $\begin{array}{l}\text { Edfu Ferroalloys } \\
\text { drain (Sector 4) }\end{array}$ & $\begin{array}{l}\text { East } \\
\text { Middle } \\
\text { West }\end{array}$ & $\begin{array}{l}25^{\circ} 0 ` 47.46804 ” / 32^{\circ} 52^{`} 19.43052^{\prime \prime} \\
25^{\circ} 0 ` 45.00961 ” / 32^{\circ} 52^{`} 45.07874^{\prime \prime} \\
25^{\circ} 0 ` 44.47403^{\prime} / 32^{\circ} 52^{`} 30.67291^{\prime}\end{array}$ & $\begin{array}{l}\text { In front of Edfu ferroalloys factory drain } \\
\text { Main channel of the River Nile } \\
\text { On the other side of Edfu ferroalloys factory }\end{array}$ \\
\hline $\begin{array}{l}S_{13} \\
S_{14} \\
S_{15}\end{array}$ & $\begin{array}{l}\text { Edfu sugar } \\
\text { factory drain } \\
\text { (Sector 5) }\end{array}$ & $\begin{array}{l}\text { East } \\
\text { Middle } \\
\text { West }\end{array}$ & $\begin{array}{l}25^{\circ} 22^{`} 4.32121^{\prime \prime} / 32^{\circ} 52^{`} 3.38562^{\prime \prime} \\
25^{\circ} 22^{\prime} 47.00592^{\prime \prime} / 32^{\circ} 51^{`} 50.50415^{\prime \prime} \\
25^{\circ} 22^{\prime} 39.41162^{\prime \prime} / 32^{\circ} 51^{`} 41.12457^{\prime}\end{array}$ & $\begin{array}{l}\text { On the other side of Edfu sugar factory drain } \\
\text { Main channel of the River Nile } \\
\text { In front of Edfu sugar cane factory drain }\end{array}$ \\
\hline
\end{tabular}




\subsubsection{Biochemical oxygen demand (BOD)}

BOD was calculated from the difference between initial and final DO (APHA, 1998).

\subsubsection{Nitrate measurement}

It was measured by using the method of Mullin and Riley (1955).

\subsubsection{Nitrite measurement}

It was carried out in $25 \mathrm{ml}$ water sample using colorimetric method (APHA, 1998).

\subsubsection{Estimation of Ammonia}

Ammonia was estimated colorimetrically using phenate method (APHA, 1998).

\subsubsection{Estimation of Orthophosphate}

It was estimated by using stannous chloride method (APHA, 1998).

\section{Water quality index (WQI)}

The WQI is identified according to the Canadian Water Quality Index (CWQI) endorsed by the Canadian Council of Ministers of the Environment (CCME, 2001). The WQI was calculated using the following equation:

$\mathrm{WQI}=100-\left[\frac{\sqrt{F 1^{2}+F 2^{2}+F 3^{2}}}{1.732}\right]$

$F_{1}$ (Scope): The $\%$ of variable that exceeds the permissible value.

$\mathrm{F} 1=\left[\frac{\text { Number of failed variables }}{\text { Total number of variables }}\right] x 100$

$F_{2}$ (Frequency): The $\%$ of separate tests for each variable that exceeds the permissible value.

$\mathrm{F} 2=\left[\frac{\text { Number of failed tests }}{\text { Total number of tests }}\right] x 100$

$F_{3}$ (Amplitude): The extent (excursion) to which the failed test reaches when it exceeds the permissible value.

$\mathrm{F} 3=\left[\frac{n s e}{0.01 \text { nse }+0.01}\right]$

Where nse $=\left[\frac{\sum \text { excursion }}{\text { Total number of tests }}\right]$

And excursion $=\left[\frac{\text { Failed tests }}{\text { Guidline value }}\right]-1$

Two sets of guidelines were used to determine the suitability of the Nile water for drinking (EWQS, 2007; WHO, 2011). Rating of water quality is classified as poor (0 $44)$, marginal $(45-64)$, fair $(65-79)$, good $(80-94)$ or excellent $(95-100)$.

\section{Statistical analysis}

All statistical calculations were achieved using SPSS (STATISTICA, 2007) statistical program version 20. In addition, the correlation coefficient $(r)$ between the measured parameters was examined.

\section{RESULTS}

\section{Major bacterial groups}


The total microbial load in the water samples obtained from the different sites of the River Nile in the governorate of Aswan, which is affected by different sources of wastewater are illustrated in Fig. (2). Remarkably, the disposal sites are affected by wastewater discharging, where the highest bacterial load of various bacterial groups under study are recorded at the disposal sites.

The highest total viable bacteria count (TBC) which grows at $22{ }^{\circ} \mathrm{C}\left(\mathrm{TBC}\right.$ at $22{ }^{\circ} \mathrm{C}$ ) recorded higher counts at disposal site of Kom Ombo drain, followed by the disposal site of Edfu sugar cane factory drain, El-Sail drain and Edfu ferroalloys factory drain (average $1800,732,325,91 \mathrm{cfu} \times 10^{3} / \mathrm{ml}$ respectively). Additionally, $\mathrm{TBC}$ at $22^{\circ} \mathrm{C}$ showed their highest values during winter season, while the lowest values were recorded during summer season (Fig. 2).

The highest values for TBC at $37{ }^{\circ} \mathrm{C}$ were recorded at El-Sail drain $\left(137 \times 10^{3}\right.$ $\mathrm{cfu} / \mathrm{ml})$, followed by Kom Ombo drain $\left(89 \times 10^{3} \mathrm{cfu} / \mathrm{ml}\right)$, then Edfu ferroalloys factory drain $\left(48 \times 10^{3} \mathrm{cfu} / \mathrm{ml}\right)$, and Edfu sugar cane factory drain $\left(26 \times 10^{3} \mathrm{cfu} / \mathrm{ml}\right)$. In Fig. (2), the $\mathrm{TBC}$ at $37^{\circ} \mathrm{C}$ is arranged seasonally in the following order: spring > winter $>$ autumn $>$ summer.

Significant value of $p<0.05$ recorded from Kom Ombo drain reveals a high exposure to thermal pollution, as it recorded higher value for thermophilic bacteria (average 259 $\mathrm{cfu} / \mathrm{ml}$ ), followed by El-Sail drain (average $172 \mathrm{cfu} / \mathrm{ml}$ ). In addition, summer season recorded the highest thermophiles, followed by winter then spring and autumn (average 60, 40, 23 and $19 \mathrm{cfu} / \mathrm{ml}$, respectively) (Fig. 2).

Spore forms bacteria (SFB) showed higher values during winter and spring (average $4 \mathrm{cfu} / \mathrm{ml}$ ), and the polluted sites at Kom Ombo drain and Edfu sugar drain showed the highest spore forming bacterial load (average $15 \mathrm{cfu} / \mathrm{ml}$ ) (Fig. 2).

In addition, the percentage increases in microbial load comparing to the main channel at the same sector, and values ranged from 649 to16668, 533 to 1172,426 to 43792 and 2855 to 13434 for total bacteria developed at $22^{\circ} \mathrm{C}$, total bacteria developed at $37^{\circ} \mathrm{C}$, spore forms bacteria and thermophilic bacteria, respectively (Fig. 3). Obviously, thermophilic bacteria and spore forms bacteria recorded higher percentage increases, and the same took place in Edfu sugar cane factory drain followed by Kom Ombo sugar cane factory drain, while the increase of the minimum percentage was recorded at Edfu ferroalloys factory drain (Fig. 3).

\section{Bacterial indicators of sewage pollution}

Similar results were obtained in the case of bacteria indicators of pollution (total coliforms, TC, faecal coliforms, FC and faecal streptococci, FS), where they are distinguished at all disposal sites (Fig. 4). The highest values were recorded at the disposal sites, particularly, El-Sail drain, which showed the highest values of total coliforms, faecal coliforms and faecal streptococci (average 1173, 550 and 17 MPN/100 $\mathrm{ml}$, respectively). In addition, the highest bacterial indicators of pollution (TC, FC, and 

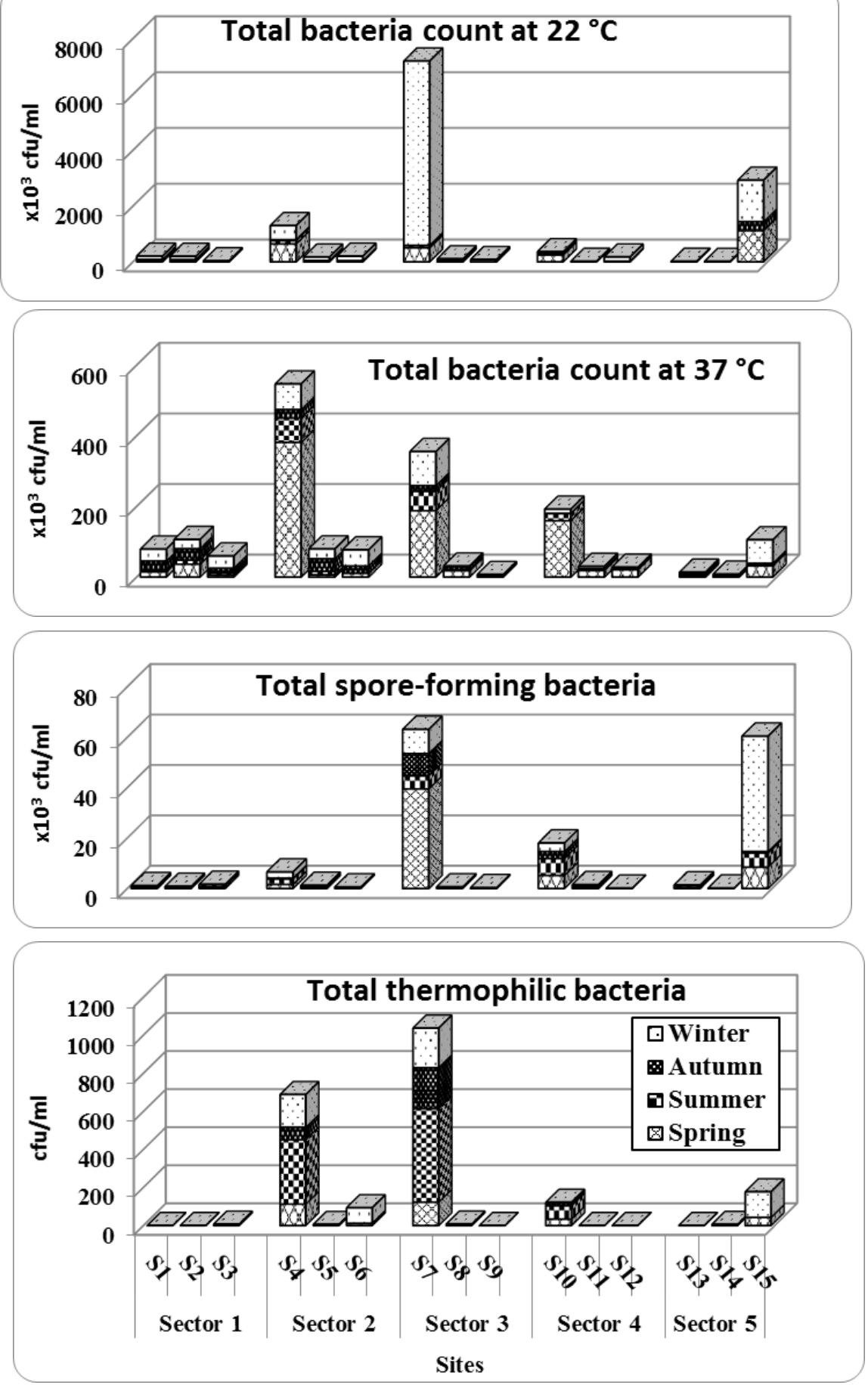

Fig. 2. Cumulative total microbial load in water samples obtained along the different sites of Aswan governorate affected by different sources of wastewater (for $S_{1}$ to $S_{15}$ refer to Fig. 1). 


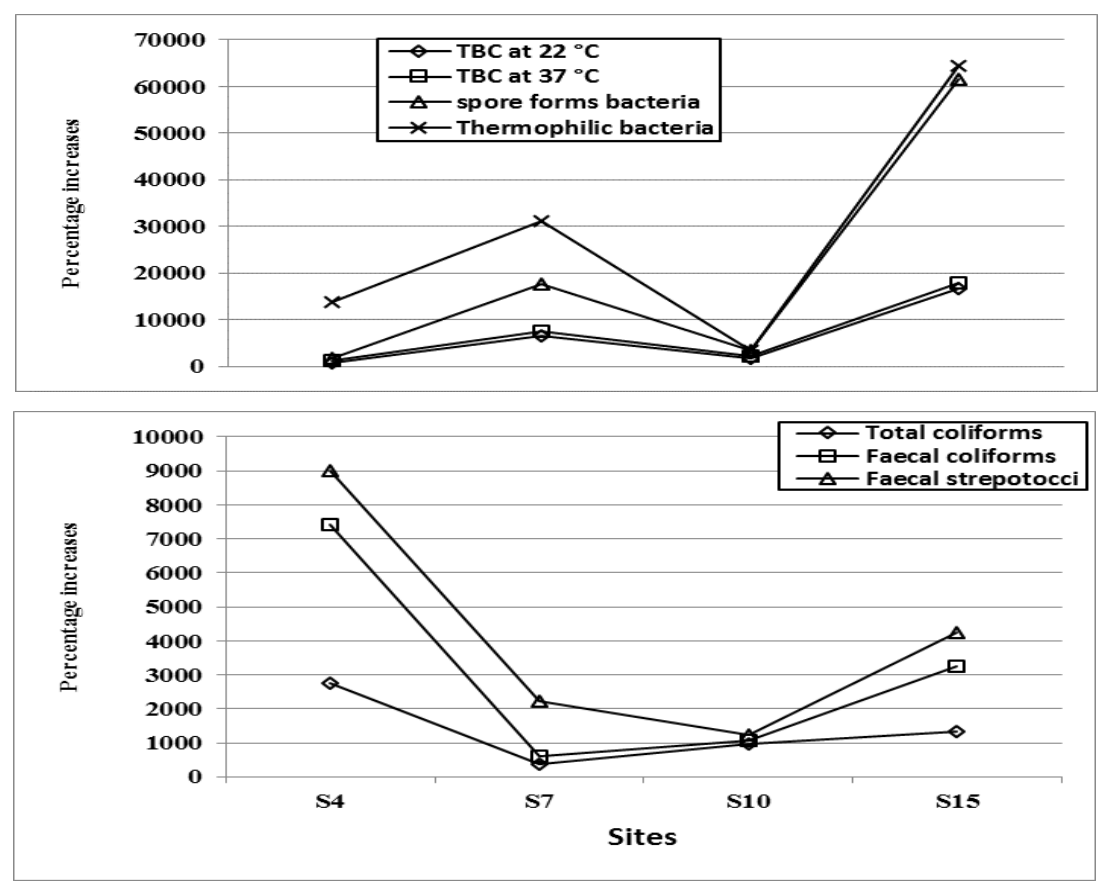

Fig. 3. Increase of microbial load percentages compared to the main channel in the same sector. (For $\mathrm{S}_{4}, \mathrm{~S}_{7}, \mathrm{~S}_{10}$ and $\mathrm{S}_{15}$ refer to Fig. 1).

FS) values were detected in the warmer seasons; spring and summer. In general, both TC, FC and FS of the River Nile water samples exceeded the permissible limits of EWQS (2007); which recommended 2/100ml, 0/100ml, 0/100ml, respectively as maximum permissible limits.

Additionally, Fig. (3) shows that the increases in the highest percentage (comparing to the main channel at the same sector) were recorded at El-Sail drain (2760, 4648 and $1583 \%$ for total coliforms, faecal coliforms and faecal streptococci, respectively), while the increases in the lowest percentage were recorded at Edfu ferroalloys factory drain (975, 89 and $158 \%$ for total coliforms, faecal coliforms and faecal streptococci, respectively).

\section{Pathogenic bacteria}

Unfortunately, investigative pathogenic bacteria, such as Salmonella sp., Shigella sp. and E. coli recorded that E. coli was detected in all samples but Salmonella sp. and Shigella sp. were detected in 22 and $30 \%$ of the samples, respectively (Fig. 5). The polluted sites (El-Sail drain, Edfu ferroalloys drain and Kom Ombo drain) recorded the highest values of E. coli (average 5.5, 3.6 and $3.4 \times 10^{3} \mathrm{cfu} / \mathrm{ml}$, respectively). Seasonally, the season of summer recorded higher values of Salmonella sp. and E. coli (average 0.1 and $4.0 \mathrm{cfu} \times 10^{3} / \mathrm{ml}$, respectively), while Shigella sp. recorded higher values in winter $\left(1.6 \times 10^{3} \mathrm{cfu} / \mathrm{ml}\right)$. 

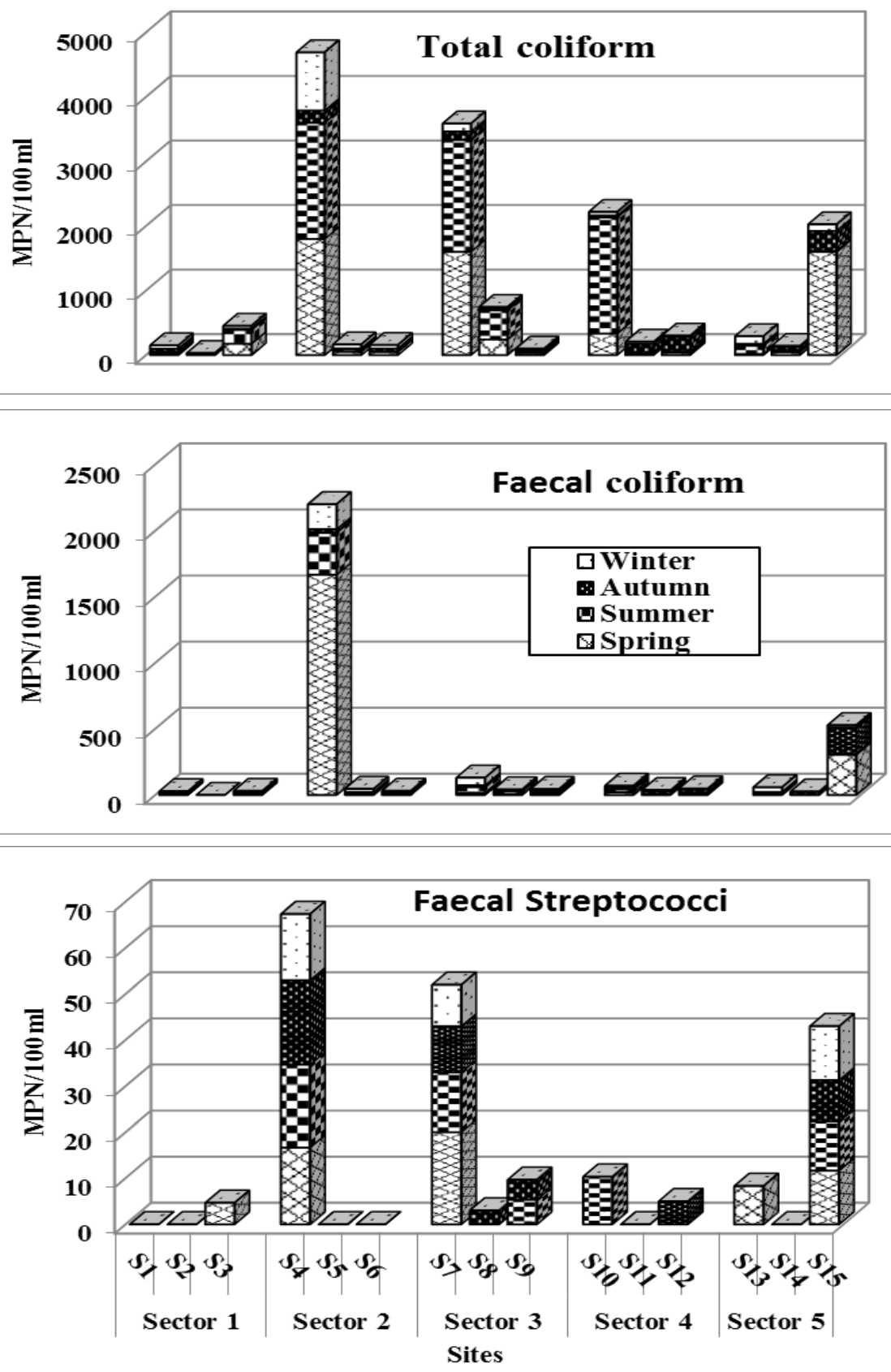

Fig. 4. Cumulative bacterial indicators of pollution in water samples obtained along the different sites of Aswan governorate affected by different sources of wastewater. $\left(S_{1}\right.$ to $\mathrm{S}_{15}$ refer to Fig. 1). 

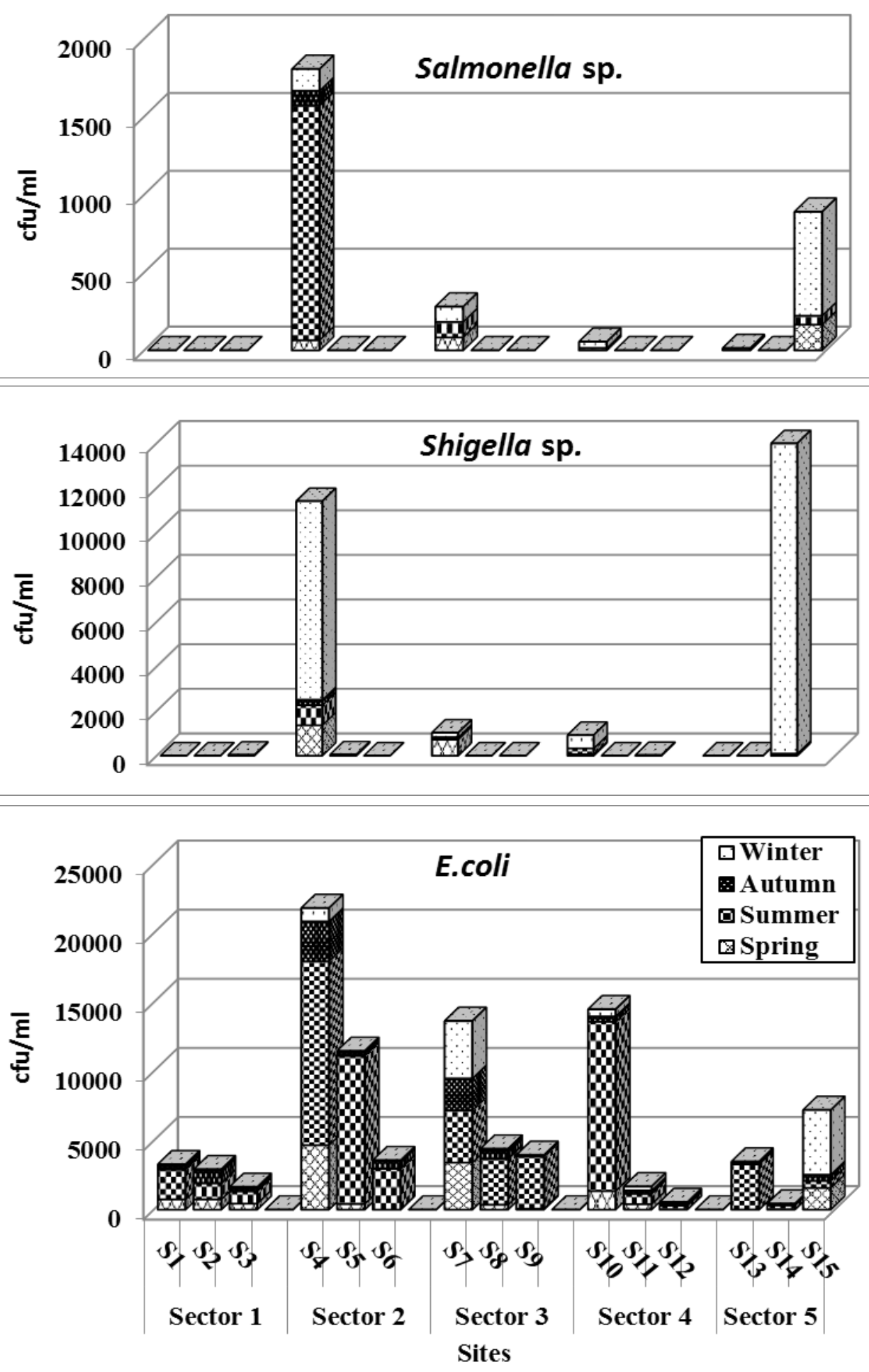

Fig. 5. Cumulative pathogenic bacteria (Salmonella sp., Shigella sp. and E. coli) in water samples obtained along the different sites of Aswan governorate affected by different sources of wastewater. $\left(S_{1}\right.$ to $S_{15}$ refer to Fig. 1$)$. 


\section{Physicochemical properties}

Additionally, the results of physicochemical analyses for the water samples obtained along the different sites of the River Nile in Aswan, affected by different sources of wastewater are illustrated in Fig. (6). This results illustrated that the disposal of wastewater affects the physicochemical characteristics of water as well as water quality. All sites of the current study that were proved to be exposed to wastes (disposal sites) (El-Sail drain, $\mathrm{S}_{4}$; Kom Ombo drain, $\mathrm{S}_{7}$; Edfu ferroalloys drain $\mathrm{S}_{10}$ and Edfu sugar cane factory drain $S_{15}$ ) recorded increases in some parameters, such as total dissolved solids and biological oxygen demand. While decreases were recorded in other parameters such as dissolved oxygen compared to other sites at the same sector (Fig. 6). This was noticed particularly in El-Sail drain samples, which recorded the highest values for electrical conductivity, EC $(678 \mu \mathrm{s} / \mathrm{cm})$, total dissolved solids, TDS (438.1 $\left.\mathrm{mgl}^{-1}\right)$, biological oxygen demand, BOD $\left(45.5 \mathrm{mgl}^{-1}\right)$, ammonia, $\mathrm{NH}_{3}\left(10669 \mu \mathrm{gl}^{-1}\right)$, nitrite, $\mathrm{NO}_{2}^{-}\left(70.4 \mu \mathrm{gl}^{-}\right.$ ${ }^{1}$ ), orthophosphate, $\mathrm{PO}_{4}{ }^{3-}\left(961.2 \mu \mathrm{gl}^{-1}\right)$ (Fig. 6). Moreover, Kom Ombo drain recorded the highest values of water temperature $\left(27.3^{\circ} \mathrm{C}\right)$ and nitrate, $\mathrm{NO}_{3}{ }^{-}\left(2733.4 \mu \mathrm{gl}^{-1}\right)$ as shown in Fig.(6). Significantly $(\mathrm{P}<0.05)$ the lowest values of hydrogen ion concentration $(\mathrm{pH})$ was recorded at Kom Ombo drain (6.89), and the lowest values of DO was recorded at El-Sail drain $\left(0.34 \mathrm{mgl}^{-1}\right)$.

\section{Water quality index (WQI)}

The obtained results showed that the investigated parameters were within the permissible limits of (EWQS, 2007) except for $\mathrm{NH}_{3}$ and $\mathrm{NO}_{2}{ }^{-}$in El-Sail drain samples. The WQI of the water samples at the selected 15 sites are illustrated in Table (1). Data showed that the area around El-Sail drain water has the lowest WQI value (55.68) and it was classified as marginal. Three areas around Kom Ombo drain, Edfu ferroalloys factory drain and Edfu sugar cane factory drain were classified as fair, and all other sites were good in their WQI ranks, while the excellent rank was not recorded for any sites.

\section{DISCUSSION}

Monitoring researches are very important for the evaluation of water quality. There are several methods (APHA, 1998; Fathi et al., 2018), and several standards such as water quality indexes (Hoseinzadeh et al., 2015; Barakat et al., 2018) are used to evaluate water quality.

In the present research, bacterial quantity (counts) and quality (types) were used as indicators of water quality, physicochemical properties and water quality index (WQI). Disposal sites recorded higher bacterial load compared to other sites in the same sectors (Fig. 2, 3, 4 \& 5), this reflects the pollution occurance resulting from the discharged effluents at those sites. Moreover, both Kom Ombo drain and Edfu sugar drain showed increased bacterial load during winter and spring, due to the fact that those two factories (Kom Ombo and Edfu sugar cane) only operate during those two seasons (from 

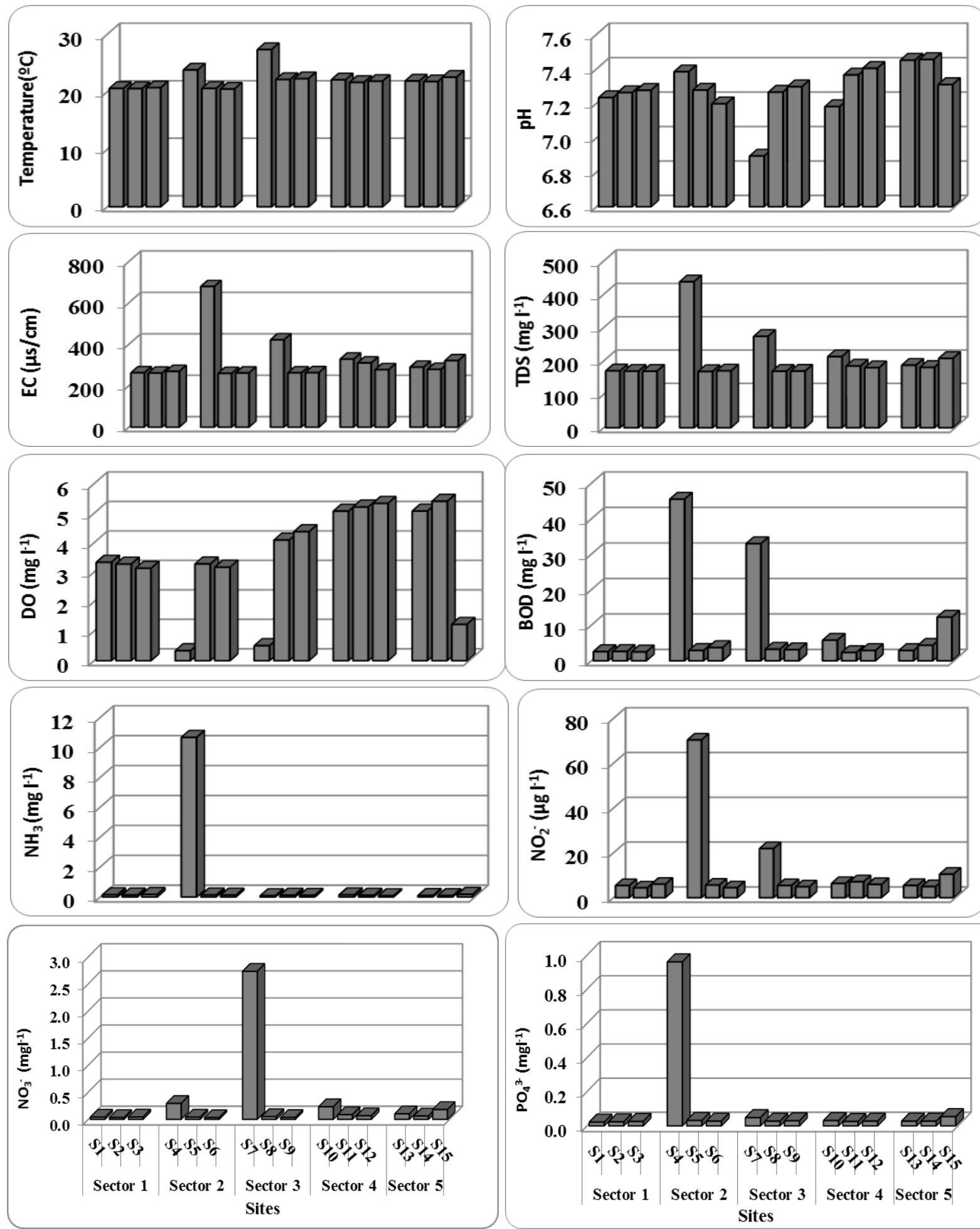

Fig. 6. Average of all physical and chemical determinations of water samples obtained along the different sites of Aswan governorate affected by different sources of wastewater. $\left(S_{1}\right.$ to $S_{15}$ refer to Fig. 1$)$. 
Table 1. The calculated values of Water Quality Index (WQI) of the River Nile water collected in Aswan governorate.

\begin{tabular}{lllllllllll}
\hline Sites & $\begin{array}{l}\text { Total } \\
\text { variables }\end{array}$ & $\begin{array}{l}\text { Failed } \\
\text { variables }\end{array}$ & $\begin{array}{l}\text { Total } \\
\text { tests }\end{array}$ & $\begin{array}{l}\text { Failed } \\
\text { Tests }\end{array}$ & F1 & F2 & Nse & F3 & WQI & Rank \\
\hline S1 & 10 & 1 & 40 & 1 & 10 & 2.5 & 0.005 & 0.497 & 94.04 & Good \\
S2 & 10 & 1 & 40 & 1 & 10 & 2.5 & 0.015 & 1.477 & 93.98 & Good \\
S3 & 10 & 1 & 40 & 2 & 10 & 5.0 & 0.057 & 5.437 & 92.82 & Good \\
S4 & 10 & 2 & 40 & 8 & 20 & 20 & 2.492 & 71.35 & $\mathbf{5 5 . 6 8}$ & Marginal \\
S5 & 10 & 1 & 40 & 4 & 10 & 10 & 0.092 & 8.466 & 90.48 & Good \\
S6 & 10 & 1 & 40 & 3 & 10 & 7.5 & 0.055 & 5.213 & 92.18 & Good \\
S7 & 10 & 2 & 40 & 5 & 20 & 12.5 & 0.354 & 26.15 & $\mathbf{7 9 . 6 6}$ & Fair \\
S8 & 10 & 1 & 40 & 2 & 10 & 5.0 & 0.061 & 5.660 & 92.76 & Good \\
S9 & 10 & 1 & 40 & 1 & 10 & 2.5 & 0.080 & 7.407 & 92.67 & Good \\
S10 & 10 & 1 & 40 & 4 & 10 & 10 & 0.482 & 32.54 & $\mathbf{7 9 . 5 1}$ & Fair \\
S11 & 10 & 1 & 40 & 2 & 10 & 5.0 & 0.202 & 16.83 & 88.32 & Good \\
S12 & 10 & 1 & 40 & 3 & 10 & 7.5 & 0.085 & 7.834 & 91.48 & Good \\
S13 & 10 & 1 & 40 & 2 & 10 & 5.0 & 0.050 & 4.761 & 92.98 & Good \\
S14 & 10 & 1 & 40 & 2 & 10 & 5.0 & 0.152 & 13.23 & 89.99 & Good \\
S15 & 10 & 1 & 40 & 4 & 10 & 10 & 0.521 & 34.21 & $\mathbf{7 8 . 6 2}$ & Fair \\
\hline
\end{tabular}

$\left(S_{1}\right.$ to $S_{15}$ refer to Fig. 1$)$.

December to June). In addition, the site around Kom Ombo drain is exposed to thermal pollution and recorded the highest water temperature value and thermophilic bacteria (Elbadry, 2019). Hence, a significant positive correlation between thermophilic bacteria and water temperature $(\mathrm{r}=0.422)$ is detected. Furthermore, the higher microbial load (TBC at $22{ }^{\circ} \mathrm{C}$ ) was recorded at Kom Ombo drain, followed by Edfu sugar drain and ElSail drain. The highest $\mathrm{TBC}$ at $37^{\circ} \mathrm{C}$ was recorded at El-Sail drain followed by Kom Ombo drain. In addition, the ratio of TBC at $22^{\circ} \mathrm{C} / \mathrm{TBC}$ at $37^{\circ} \mathrm{C}$ ranged from 0.13 to 87.8 , and the lowest ratio was recorded at the disposal sites. This indicates that the Nile waters are proved to be under pollution effect, especially at the disposal sites (compared to the permissible standard of 10:1 according to the ministry of health (1939).

The pollution sites recorded increases in coliform counts, which led to fecal pollution occurance in those sites (WHO, 1963). Highest counts of fecal coliform were recorded at the El-Sail drain region, during four seasons, due to large quantities of sewage, domestic and industrial wastes being discharged in El-Sail drain (Ali et al., 2015). Generally, the highest numbers of indicator bacteria (TC, FC, and FS) were detected in warm seasons (spring and summer), which can be attributed to high temperatures and wastewater discharged during those seasons (Abu-Shady et al., 1996; Isobe et al., 2004). The FC/FS ratio of both El-Sail and Edfu sugar drains was about 32.7 and 12.3, respectively. This indicates the existence of sewage contamination, particularly, where the ratio of FC/FS determines the source of feces whether it is human $(>4)$ or animal $(<0.7)$ (Geldreich, 1976).

El-Sail drain recorded the highest value of Salmonella sp. and E. coli; a result that agrees with that reported by Ali et al. (2015). The presence of salmonella in the River Nile water should be regarded seriously due to its effect on human health (Minor, 2003). 
The significant positive correlation between Salmonella sp. and Shigella sp. $(r=0.584)$ and E. coli $(r=0.586)$ indicated that all are originated from the same source.

Moreover, El-Sail drain showed the highest EC and TDS values, as shown in Fig. (6). This reflects the high quantities of ions in the water, and EC changes in the Nile water that can be used as an indication of potential effects (Abdel-Satar et al., 2017). The present findings coincide with those of Ali et al. (2015) and Elbadry (2019). The increase of EC and TDS values during the cold seasons (winter and autumn) is attributed to the increase of soluble salts, cations and anions, as a result of low water levels during the drought period (Abdo et al., 2010). The TDS showed a positive correlation with EC ( $r=0.991, \mathrm{n}=180$ ), which means that both TDS and EC are dependent on each other (Salaah et al., 2018).

The lowest dissolved oxygen (DO) values were recorded at the sites exposed to pollution, which may be due to its consumption by the oxidation of nitrogenous compounds (Deai et al., 1991) and organic matter (Loagu, 1993). Additionally, the highest BOD values were recorded at areas under the impact of pollution which reflect the large load of organic matter discharged into the River Nile at those sites (Elbadry, 2019). The BOD showed negative significant correlations with DO ( $r=-0.629 \mathrm{n}=180)$ and this result is in agreement with the result obtained by El-Sayed (2011). There are significant positive correlations between BOD and TBC at $37{ }^{\circ} \mathrm{C}$, thermophilic bacteria, Salmonella sp., E. coli, TC, FC and FS ( $\mathrm{r}=0.609,0.817,0.636,0.568,0.766,0.573$ and $0.825 \mathrm{n}=180$ respectively), and this may be due to the increasing rate of oxygen consumption through different biological activities of those microorganisms.

El-Sail drain showing the highest $\mathrm{NH}_{3}$ and $\mathrm{NO}_{2}^{-}$values agrees with the findings of Ali et al. (2015), Abdel-Satar et al. (2017) and Elbadry (2019). Notably, the increase of ammonia concentration may be attributed to the activity of denitrifying bacteria (Ghallab, 2000). Kom Ombo drain contained the highest level of $\mathrm{NO}_{3}{ }^{-}$; a result that matches with that of Elbadry (2019). Significantly, the polluted area showed the highest $\mathrm{PO}_{4}{ }^{3-}$ level, where El-Sail drain recorded the highest level due to the considerable amounts of sewage, domestic and industrial wastes discharged directly into the River Nile at this site. Moreover, significant positive correlations of $\mathrm{PO}_{4}{ }^{3-}$ with $\mathrm{BOD}(r=0.689$, $\mathrm{n}=180$ ) indicates that a large amount of $\mathrm{PO}_{4}{ }^{3-}$ in the River Nile water was associated with organic matter (Abdel-Satar, 2005).

To illustrate, the low WQI values were recorded at polluted sites with the lowest value at El-Sail drain water. The current results are in agreement with those obtained by Elbadry (2019), who reported that the water of the River Nile in Aswan and Luxor governorates was classified as slightly to moderately polluted except for that collected from El-Sail drain sector. The previous author added that the afore- mentioned sector was considered seriously polluted as a result of the discharged wastes from El-Sail drain containing high load of organic pollutants. 


\section{CONCLUSION}

The River Nile water is affected by pollution inputs from untreated domestic and industrial wastewater. Pollutants enter the River Nile through direct discharge or runoff. This study revealed that both El-Sail drain and Kom Ombo drain are the main sources of the River Nile pollution in Aswan. Therefore, wastewater effluent must be treated before being discharged into the Nile.

\section{REFERENCES}

Abdel-Satar, A.M. (2005). Water quality assessment of River Nile from Idfo to Cairo Egypt. J. Aquat. Res. 31 (2): 200-223.

Abdel-Satar, A.M. and Elewa, A.A. (2001). Water quality and environmental assessments of the River Nile at Rosetta branch. The Second International Conference and Exhibition for Life and Environment. Alexandria, Egypt. 3-5 April, pp: 136 - 164.

Abdel-Satar, A.M.; Ali, M.H. and Goher, M.E. (2017). Indices of water quality and metal pollution of Nile River, Egypt. The Egyptian Journal of Aquatic Research 43(1): 21-29.

Abdo, M.H.; Sabae, S. Z.; Haroon, B.M.; Refaat, B.M. and Mohammed, A.S. (2010). Physicochemical characteristics, microbial assessment and antibiotic susceptibility of pathogenic bacteria of Ismailia Canal water, River Nile, Egypt. Journal of American Science 6(5): 234-250.

Abu-Shady, M.R.; El-Moatassem, M.; Heikal, M.T. and Khalafalla, G.M. (1996). Microbiological quality of the River Nile stretch flows through Cairo. The Second International Conference on Potable Water Management and Water Treatment Technologies, Cairo Aqua-Tech, 96.

Agricultural Policy Reform Program, APRP, (2002). Survey of Nile System Pollution Sources, Ministry of Water Resources and Irrigation, Report No. 64, Cairo, Egypt.

Ahmed, A.T. (2015). Environmental Impacts of Industrial Wastewater Effluents on Water Quality of Nile River. International Journal of Water Resources and Arid Environments 4(2): 146-153.

Ali, G.H.; El-Taweel, G.E.; Ghazy, M.M. and Ali, M.A. (2000). Microbiological and chemical study of the Nile River water quality. International Journal of Environmental Studies 58: 47-69.

Ali, S.M.; Fouda, A.H.; El-Ghamry, A.A. and AbdEImonem, H. (2015). Evaluation of El-Seel drain water quality and their effect on river Nile pollution. ESAIJ, 10(12): 462475 . 
Ali, S.M.; Othman, A.A. and Abbas, M.T. (2016). Bacteriological Monitoring for the Northern Khors of Lake Nasser, Egypt. Research Journal of Microbiology 11(1/2): 80-92.

Ali, S.M.; Sabae, S.Z.; Fayez, M.; Monib, M. and Hegazi, N.A. (2011). The influence of agro-industrial effluents on River Nile pollution. Journal of Advanced Research 2(1): $85-95$.

Al-Shujairi, S.O.H. (2013). Develop and apply water quality index to evaluate water quality of Tigris and Euphrates Rivers in Iraq. International Journal of Modern Engineering Research 3(4): 2119-2126.

American public Health Association, APHA, (1998). Standard methods for the examination of water and wastewater. New York.

Awadallah, R.M.; Ismail, S.S.; Abd El Aal, M.T. and Soltan, M.E. (1993). Investigation of drinking and Nile water samples of Upper Egypt. Water SA. 19 (3):217230.

Backman, B.; Bodiš, D.; Lahermo, P.; Rapant, S. and Tarvainen, T. (1998). Application of a groundwater contamination index in Finland and Slovakia. Environmental Geology 36(1-2): 55-64.

Barakat, A.; Meddah, R.; Afdali, M. and Touhami, F. (2018). Physicochemical and microbial assessment of spring water quality for drinking supply in Piedmont of BéniMellal Atlas (Morocco). Physics and Chemistry of the Earth, Parts A/B/C, 104: 39-46.

Canadian Council of Ministers of the Environment, CCME, (2001). Canadian water quality guidelines for the protection of aquatic life: CCME Water Quality Index 1.0, User's Manual. In: Canadian environmental quality guidelines, 1999, Canadian Council of Ministers of the Environment, Winnipeg.

Canli, M. and Kalay, A. (1988). Level of Heavy Metals ( $\mathrm{Cd}, \mathrm{Pb}, \mathrm{Cu}, \mathrm{Cr}$ and $\mathrm{Ni}$ ) in Tissue of Cyprinus carpio, Barbus capito and Chondrostoma regiumfrom the Seyhan river, Turkey. Turkish journal of zoology 22: 149-157.

Deai, J.; Yida, T.; Gong, Y.; Jianrong, Z. and Yicheng, S. (1991). Factors affecting the relationship between the NBOD values and the amounts of nitrogenous pollutants. Afield study on Lee River. Waqt. Res., 25: 485-489.

Egyptian drinking water quality standards, EWQS, (2007). Ministry of Health, Population Decision number 458.

Elbadry, A.O. (2019). Distribution, sorption and adsorption of some heavy metals in water and sediment from River Nile, Egypt. M.Sc. Thesis, Faculty of Science, Aswan University, Egypt.

El-Sayed, S.M.M. (2011). Physicochemical studies on the impact of pollution up on the Nile River branches, Egypt. M.Sc. Thesis, Faculty of Science, Benha University, Egypt. 
El-Sheekh, M.M.; Haroon, A.M. and Sabae, S. (2018). Seasonal and spatial variation of aquatic macrophytes and phytoplankton community at El-Quanater El-Khayria River Nile, Egypt. Beni-Suef University Journal of Basic and Applied Sciences.

Fathi, E.; Zamani-Ahmadmahmoodi, R. and Zare-Bidaki, R. (2018). Water quality evaluation using water quality index and multivariate methods, Beheshtabad River, Iran. Applied Water Science 8(7): 210.

Geldreich, E.E. (1976). Faecal coliform and faecal streptococcus density relationships in waste discharges and receiving waters. Critical Rev. Environ. Contr. 6: 349-369.

Ghallab, M.H. (2000). Some physical and chemical changes on the River Nile downstream of Delta barrage at El-Rahawy drain. M.Sc. Thesis, Faculty of Science, Ain Shams University, Egypt.

Hoseinzadeh, E.; Khorsandi, H.; Wei, C. and Alipour, M. (2015). Evaluation of Aydughmush river water quality using the national sanitation foundation water quality index (NSFWQI), river pollution index (RPI), and forestry water quality index (FWQI). Desalination and Water Treatment, 54(11): 2994-3002.

Ismail, S.S. and Ramadan, A. (1995). Characterisation of Nile and drinking water quality by chemical and cluster analysis. Sci. Total Environ. Dec. 1, 173-174: 69-81.

Isobe, K.O.; Tarao, M. Chiem, N.H.; Minh, LeY. and Takada, H. (2004). Effect of environmental factors on the relationship between faecal indicator bacteria in tropical (Mekong Delta) and temperature (Tokyo) freshwaters. Applied and Environmental Microbiology 79(2): 814-821.

Loagu, E. (1993). The dynamics of water quality in Rivers. In: "Waters pollution load and quality in Estonia Environmental Reports” Pylvanainen, M. (Ed.), Helsinki. 22-29.

Ministry of Health, (1939). The bacteriological examination of water and water supplies. Rev. Rept. Public Health and Medical Subjects (Ed.). London 73.

Minor, Le (2003). The genus Salmonella. In: The Prokaryotes: An Evolving Electronic Resource for the Microbiological Community, electronic release 3.14, 3th; Dworkin, M., Falkow, S., Rosenberg, E. (Eds.). Springer-Verlag: New York, NY, USA.

Mullin, J.B. and Riley, J.P. (1955). The Spectrophotometric Determination of Nitrate in Natural Waters, with Particular Reference to Sea-Water. Analytica Chimica Acta, 12: 464 -480 .

Nda, A.A.; Idi-Ogede, A.M.; Musa, M.A.; Yakubu, S.O. and Masaya, A.H. (2018). Effects of aquatic pollution on fish health: A Review. Journal of Scientific and Engineering Research 5(4):36-46. 
Othman, A.A.; Ali, S.M. and Abbas, M.T. (2016). Microbial water quality and diazotrophic bacteria community in Lake Nasser Khors, Egypt. Res J Environ Toxicol. 10: 100-108.

Poonam, T.; Tanushree, B. and Sukalyan, C. (2013). Water quality indices-important tools for water quality assessment: a review. International Journal of Advances in chemistry $1(1): 15-28$.

Rawway, M.; Kamel, M.S. and Abdul-Raouf, U.M. (2016). Microbial and physicochemical assessment of water quality of the River Nile at Assiut Governorate (Upper Egypt). Journal of Ecology of Health \& Environment 14(1): 7-14.

Salaah, S.M.; Khalil, M.T.; Gad, N.S. and Ahmed, N.A.M. (2018). Physico-chemical characteristics and physiological changes in Oreochromis niloticus from Rosetta branch of the River Nile. European Chemical Bulletin 7(2): 63-71.

Soltan, M.E. (1991). Study of River Nile water pollution. P.D. Fac. Sci. Aswan, Assiut University, Egypt.

STATISTICA (2007). Stat Soft-Inc for Windows Release, U.S.A.

Wepener, V.; Euler, N.; Van Vuren, J.H.J.; Du Preez, H.H. and Kohler, A. (1992). The development of an aquatic toxicity index as a tool in the operational management of water quality in the Olifants River (Knsger National Park). Koedoe 35(2): 1-9.

World Health Organization, WHO, (1963). International Drinking Water Standard: Geneva.

World Health Organization, WHO, (2011). Guidelines for drinking-water quality, fourth edition.

Zakhem, B.A. and Hafez, R. (2015). Heavy metal pollution index for groundwater quality assessment in Damascus Oasis, Syria. Environmental earth sciences 73(10): 65916600. 